\title{
EDUCAÇÃo Escolar QUilombola, EdUCAÇÃo daS RELAÇões ÉtNico-RACIAIS E PARA O ENSINO DE História E Cultura Afro-Brasileira e Africana
}

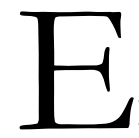

sse número da Revista Cadernos de Pós-graduação tratando de questões pertinentes a Educação Escolar Quilombola, Educação das Relações Étnico-Raciais e para o Ensino de História e Cultura Afro-Brasileira e Africana nos oferece a oportunidade de tornar público um conjunto de pesquisadores preocupados em estudar e refletir sobre essa temática; que se mostra cada vez mais atual e decisiva para a consolidação democrática e o pleno exercício da cidadania na sociedade brasileira contemporânea.

Em que pese uma série de críticas sociais, sempre lembradas e proferidas no debate público, inclusive, de forma pejorativa, não se pode desconsiderar a importância da aprovação e a implementação das políticas de ações afirmativas que vem sendo adotadas no país; mormente, aquelas que dizem respeito ao ingresso nas relações de ensino e aprendizagem de crianças, jovens e adultos historicamente excluídos das experiências educativas no país.

No Brasil as elites políticas, econômicas e culturais sempre se esmeraram em produzir e disseminar o discurso de que vivemos num país cordial e desprovido de quaisquer preconceitos étnico-raciais; embora o que a realidade insiste em nos

Cadernos de Pós-graduação, São Paulo, v. 17, n. 1, p. 8-13, jan./jun. 2018. 
mostrar é a vigência de formas ardilosas de disfarçar o apartheid social reinante entre nós.

Desde o período colonial foram sendo construídos mitos que tratavam, inicialmente, os povos indígenas e, depois, os africanos como bárbaros, indolentes ou até mesmo como seres inferiores que não teriam outro papel na sociedade que não fossem aqueles destinados ao oferecimento de sua força de trabalho, escravizada e brutalizada.

Os povos indígenas foram sendo gradativa e impetuosamente exterminados, e o fim da escravatura não foi acompanhado do oferecimento de oportunidades e da adoção de políticas capazes de assegurarem o ingresso dos afrodescendentes na nova ordem social republicana que surgia no país.

Pelo contrário, rapidamente, foram surgindo novos mitos associados ao chamado arianismo, ao antissemitismo e ao repúdio à diversidade cultural, ao fortalecimento do etnocentrismo e das teorias pseudocientíficas da superioridade racial e da eugenia entre uma gama significativa de intelectuais, políticos e da sociedade brasileira.

Em meados do século XX, os indígenas, os afrodescendentes e os imigrantes chineses, japoneses e aqueles que eram provenientes de outras partes do mundo eram vistos como "tipos exóticos" e tratados de tal modo a reforçarem as visões estereotipadas, etnocentristas, racistas em voga na época e, aliás, com desdobramentos sociais que perduraram no tempo e perversamente alcançaram os nossos dias!

Mas, também, por essa época, iniciativas como aquelas realizadas, em 1951, por Afonso Arinos e Gilberto Freyre, no encaminhamento ao Congresso Nacional uma proposta de princípio constitucional, mais tarde transformada na Lei Afonso 
Arinos, preconizando a punição para os que praticavam atos discriminatórios contra as pessoas pela cor e pela raça nos lugares públicos.

Nesse processo, as vozes da negritude se mostraram combativos e presentes com a criação da Frente Negra Brasileira (FNB), em 1931, a realização da Primeira Convenção do Negro Brasileiro, em 1945. Também, outros momentos se mostraram importantes na luta pela afirmação dos direitos de uma cidadania plena aos afrodescendentes, como foi o caso da criação do Teatro Experimental do Negro, em 1944, por Abdias do Nascimento; além da fundação, em 1949, da União dos Homens de Cor, com o objetivo de defender a criação de escolas, cooperativas e serviços médicos para os moradores dos bairros pobres, então, conhecidos como favelas e, assim, garantir a alfabetização da população afro-brasileira.

$\mathrm{Na}$ avaliação do professor Florestan Fernandes (1972), os protestos perpetrados pela população afrodescendente se caracterizavam pela resistência e pelo conformismo, trazendo uma perspectiva de caráter de busca pela integração e não pela ruptura com a ordem estabelecida, produzindo, então, uma revolução dentro da ordem.

A partir das décadas de 1970 e 1980 os movimentos sociais e populares intensificaram as reivindicações pela conquista da cidadania no Brasil, com as populações indígenas, ribeirinhas, caiçaras, expulsas pelas barragens, quilombolas e os povos das florestas procurando colocar na ordem do dia a preservação e a valorização do seu habitat e do seu modo de vida e do congraçamento dos seus direitos sociais.

Atualmente, a Constituição do Brasil, promulgada em 1988, reconhece em seu Artigo $5^{\circ}$ que todos são iguais perante a lei, sem distinção de qualquer natureza, 
garantindo-se aos brasileiros e aos estrangeiros residentes no país a inviolabilidade do direito à vida, à liberdade, à igualdade, nos seguintes termos:

[...] XLI - a lei punirá qualquer discriminação atentatória dos direitos e liberdades fundamentais;

XLII - a prática do racismo constitui crime inafiançável e imprescritível, sujeito à pena de reclusão, nos termos da lei; [...]

Evidentemente, é muito importante termos superado algumas das mais duras e cruentas adversidades políticas e culturais e alcançando essa igualdade jurídica na contemporaneidade brasileira; mas também é de igual importância reconhecer que as diferenças econômicas e sociais são enormes, produzindo dados alarmantes de concentração de renda e o espraiar da miséria, da violência desmedida e a impossibilidade de milhões de brasileiros terem acesso à moradia, à escola, à água potável e o acesso ao saneamento básico, ao trabalho e aos serviços de saúde, enfim, as condições elementares que possam dignificar suas vidas.

Não bastasse esse quadro de profunda e sórdida penúria social é preciso lembrar que teima em persistir no Brasil uma mentalidade preconceituosa que de posse dos aparatos eletrônicos e midiáticos dissemina massivamente visões estereotipadas e de caráter racista do mundo. A superação dessas dificuldades é uma tarefa histórica que todos aqueles que atuam no universo educacional jamais poderiam deixar de abraçar!

A seguir apresentamos uma contribuição na consecução desse auspicioso desafio.

$\mathrm{Na}$ seção dossiê temático, contamos com os seguintes manuscritos: Multiculturalismo e relações étnico-raciais na educação da primeira infância, de Adelmir 
Fiabani, Camila Chiodi Agostini e Jorge dos Santos de Souza; A educação escolar do indígena brasileiro, de Claudinei de Aro Poço; Arte para a diversidade e cidadania, de Ana Laura Figueiro de Sousa e Andresa Carvalho Lopes Pires; Sociologia do Brasil negro: a pedagogia do pensamento de Clóvis Moura, de Wellington Narde Navarro da Costa; Quinze anos da lei 10639/2003: algumas reflexões dos seus antecedentes históricos, sua importância e os desafios para sua efetivação, de Cinthia Nolacio de Almeida Maia; Educação quilombola: estabelecimento e autoafirmação da identidade e cultura negra através da instituição escolar, de Esther Costa Mendonça, Karla Colares Vasconcelos e Shérida Nayara Alves da Silva e A instrução pública da criança quilombola paranaense na Primeira República, de Lucia Mara de Lima Padilha.

Na seção artigos, são os seguintes manuscritos: Tecnologias assistivas em classes hospitalares: possibilidades para inclusão de crianças e adolescentes com deficiência em tratamento oncológico, de Adriana da Silva Ramos de Oliveira, Elisangela Castedo Maria do Nascimento e Valdênia Rodrigues Fernandes Eleotério; A evasão escolar na educação profissionalizante técnica, de Marcelo Beneti; Possibilidades para pensar o processo de aquisição da linguagem pelos CODAS, de Priscilla Verona; A pesquisa colaborativa e suas contribuições para a formação dos futuros professores: o que dizem os graduandos, de Ana Maria Mendes Sampaio e José Rubens Lima Jardilino; A contribuição do educador Jan Amos Comenius para a primeira infância, de Renata Augusta Bollis.

Esse número da Cadernos também conta com as seguintes resenhas: Racismo e educação: (des) caminhos da lei no 10.630/2003, de Mauricio Pedro da Silva; Práticas pedagógicas e a formação continuada na educação infantil I, de Rafaele Paulazini Majela dos Santos; Práticas pedagógicas e a formação continuada na 
educação infantil II, de Claudia Zanatto Fernandez e, ainda, A dialética invertida e outros ensaios, de Vinicius Carlos da Silva

Agradecemos o interesse em nosso trabalho editorial e desejamos boa leitura a todos!

Ligia Vercelli

Carlos Baner

\section{REFERÊNCIAS}

BRASIL. Constituição Federal de 1988. Promulgada em 5 de outubro de 1988. Disponível em:

http://www.senado.leg.br/atividade/const/con1988/con1988 atual/art 5 asp Acesso em 07 de maio de 2018.

FERNANDES, Florestan. O negro no mundo dos brancos. São Paulo: Difel, 1972. 